\title{
Mediterranean Diet, Alzheimer Disease Biomarkers, and Brain Atrophy in Old Age
}

Tommaso Ballarini, PhD, Debora Melo van Lent, PhD, Julia Brunner, MSc, Alina Schröder, MSc, Steffen Wolfsgruber, PhD, Slawek Altenstein, Dipl-Psych, Frederic Brosseron, PhD, Katharina Buerger, MD, Peter Dechent, PhD, Laura Dobisch, MSc, Emrah Düzel, MD, Birgit Ertl-Wagner, MD, Klaus Fliessbach, MD, Silka Dawn Freiesleben, MSc, Ingo Frommann, Dipl-Psych, Wenzel Glanz, MD, Dietmar Hauser, Dipl-Psych, John Dylan Haynes, PhD, Michael T. Heneka, MD, Daniel Janowitz, MD, Ingo Kilimann, MD,

Christoph Laske, MD, Franziska Maier, MD, Coraline Danielle Metzger, MD, Matthias H. Munk, MD,

Robert Perneczky, MD, Oliver Peters, MD, Josef Priller, MD, Alfredo Ramirez, MD,

Boris-Stephan Rauchmann, MD, Nina Roy, PhD, Klaus Scheffler, PhD, Anja Schneider, MD, Annika Spottke, MD, Eike Jakob Spruth, MD, Stefan J. Teipel, MD, Ruth Vukovich, MD, Jens Wiltfang, MD, Frank Jessen, MD, and Michael Wagner, PhD, on behalf of the DELCODE Study Group

Neurology ${ }^{\circledR}$ 2021;96:e2920-e2932. doi:10.1212/WNL.0000000000012067

\section{Abstract}

\section{Objective}

To determine whether following a Mediterranean-like diet ( $\mathrm{MeDi}$ ) relates to cognitive functions and in vivo biomarkers for Alzheimer disease $(\mathrm{AD})$, we analyzed cross-sectional data from the German DZNE-Longitudinal Cognitive Impairment and Dementia Study.

\section{Method}

The sample $(\mathrm{n}=512$, mean age $69.5 \pm 5.9$ years $)$ included 169 cognitively normal participants and individuals at higher $\mathrm{AD}$ risk ( 53 with relatives with $\mathrm{AD}, 209$ with subjective cognitive decline, and 81 with mild cognitive impairment). We defined MeDi adherence according to the food frequency questionnaire. Brain volume outcomes were generated via voxel-based morphometry on T1-MRI, and cognitive performance was assessed with an extensive neuropsychological battery. AD-related biomarkers $\left(\beta\right.$-amyloid $42 / 40\left[\mathrm{~A} \beta_{42 / 40}\right]$ ratio, phosphorylated tau 181 [pTau181]) in CSF were assessed in $\mathrm{n}=226$ individuals. We analyzed the associations between $\mathrm{MeDi}$ and outcomes with linear regression models controlling for several covariates. In addition, we applied hypothesis-driven mediation and moderation analysis.

\section{Results}

Higher MeDi adherence related to larger mediotemporal gray matter volume $(p<0.05$ familywise error corrected), better memory $(\beta \pm \mathrm{SE}=0.03 \pm 0.02 ; p=0.038)$, and less amyloid $\left(\mathrm{A} \beta_{42 / 40}\right.$ ratio, $\beta \pm \mathrm{SE}=0.003 \pm 0.001 ; p=0.008)$ and $\mathrm{pTau} 181(\beta \pm \mathrm{SE}=-1.96 \pm 0.68 ; p=0.004)$ pathology. Mediotemporal volume mediated the association between MeDi and memory (40\% indirect mediation). Finally, MeDi favorably moderated the associations among $A \beta_{42 / 40}$ ratio, pTau181, and mediotemporal atrophy. Results were consistent correcting for APOE- 44 status.

\author{
Correspondence \\ Dr. Ballarini \\ tommaso.ballarini@dzne.de
}

MORE ONLINE

\section{- CME Course}

NPub.org/cmelist

From the German Center for Neurodegenerative Diseases (DZNE) (T.B., D.M.v.L., J.B., A.Schröder, S.W., F.B., K.F., I.F., M.T.H., N.R., A. Schneider, A. Spottke, F.J., M.W.), Bonn, VenusbergCampus 1, Bonn, Germany; University of Texas Health Science Center at San Antonio (D.M.v.L.); Department of Neurodegeneration and Geriatric Psychiatry (S.W., F.B., K.F., M.T.H., A. Schneider, M.W.), University Hospital Bonn, Venusberg-Campus 1; German Center for Neurodegenerative Diseases (DZNE) (S.A., O.P., J.P., E.J.S.); Department of Psychiatry and Psychotherapy (S.A., J.P., E.J.S.), Charité, Charitéplatz 1, Berlin; German Center for Neurodegenerative Diseases (DZNE, Munich) (K.B., R.P.); Institute for Stroke and Dementia Research (ISD) (K.B.), University Hospital, LMU Munich; MR-Research in Neurology and Psychiatry (P.D.), Georg-August University Göttingen; German Center for Neurodegenerative Diseases (DZNE) (L.D., E.D., W.G., C.D.M.); Institute of Cognitive Neurology and Dementia Research (IKND) (L.D., E.D., C.D.M.), Otto-von-Guericke University, Magdeburg; Institute for Clinical Radiology (B.E.-W.), Ludwig-Maximilians-University, Munich; Charité Universitätsmedizin Berlin (S.D.F., D.H., O.P.), Department of Psychiatry and Psychotherapy, Campus Benjamin Franklin; Bernstein Center for Computational Neuroscience (J.D.H.), Charité Universitätsmedizin, Berlin; Institute for Stroke and Dementia Research (ISD) (D.J.), University Hospital, LMU Munich; German Center for Neurodegenerative Diseases (DZNE) (I.K., S.J.T.); Department of Psychosomatic Medicine (I.K., S.J.T.), Rostock University Medical Center; German Center for Neurodegenerative Diseases (DZNE) (C.L., M.H.M.); Section for Dementia Research (C.L., M.H.M.), Hertie Institute for Clinical Brain Research and Department of Psychiatry and Psychotherapy, University of Tübingen; Department of Psychiatry (F.M., A.R., F.J.), University of Cologne, Medical Faculty; Department of Psychiatry and Psychotherapy (R.P., B.R.), University Hospital, LMU Munich; Munich Cluster for Systems Neurology (SyNergy) (R.P.) Munich, Germany; Ageing Epidemiology Research Unit (AGE) (R.P.), School of Public Health, Imperial College London, UK; Department for Biomedical Magnetic Resonance (K.S.), University of Tübingen; Department of Neurology (A. Spottke), University of Bonn, VenusbergCampus 1; Department of Psychiatry and Psychotherapy (R.V., J.W.), University Medical Center Goettingen, University of Goettingen; German Center for Neurodegenerative Diseases (DZNE) (J.W.), Goettingen, Germany; Neurosciences and Signaling Group (J.W.), Institute of Biomedicine (iBiMED); Department of Medical Sciences (J.W.), University of Aveiro, Portugal; and Excellence Cluster on Cellular Stress Responses in Aging-Associated Diseases (CECAD) (F.J.), University of Cologne, Germany.

Go to Neurology.org/N for full disclosures. Funding information and disclosures deemed relevant by the authors, if any, are provided at the end of the article.

Coinvestigators are listed at links.Iww.com/WNL/B405. 


\section{Glossary}

$\mathbf{A} \beta=\beta$-amyloid $; \mathbf{A D}=$ Alzheimer disease $; \mathbf{B M I}=$ body mass index; CAT12 = Computational Anatomy Toolbox; CERAD = Consortium to Establish a Registry for Alzheimer's Disease; CI = confidence interval; DELCODE = DZNE-Longitudinal Cognitive Impairment and Dementia Study; EPIC = European Prospective Investigation of Cancer; est $=$ effect estimate; FFQ = food frequency questionnaire; FWE = family-wise error; $\mathbf{M C I}=$ mild cognitive impairment; $\mathbf{M e D i}=$ Mediterranean diet; PREDIMED = Prevención con Dieta Mediterránea; $\mathbf{p}$ Tau181 = phosphorylated tau 181; ROI = region of interest; $\mathbf{S C D}=$ subjective cognitive decline; SPM12 = Statistical Parametric Mapping.

\section{Conclusion}

Our findings corroborate the view of $\mathrm{MeDi}$ as a protective factor against memory decline and mediotemporal atrophy. They suggest that these associations might be explained by a decrease of amyloidosis and tau pathology. Longitudinal and dietary intervention studies should further examine this conjecture and its treatment implications.

Healthy dietary patterns such as the Mediterranean diet $(\mathrm{MeDi})$ might reduce the risk of dementia and cognitive decline. ${ }^{1-4} \mathrm{Al}-$ though contrasting findings have been reported as well, ${ }^{5,6}$ encouraging results were provided by the Prevención con Dieta Mediterránea (PREDIMED) study, a randomized clinical trial in which a MeDi intervention was associated with both improved cognitive functioning ${ }^{7}$ and reduced incident mild cognitive impairment $(\mathrm{MCI}) .{ }^{8}$ Likewise, adherence to $\mathrm{MeDi}$ could diminish the conversion rate from MCI to dementia., ${ }^{9,10}$

At the biomarker level, MeDi has been associated with preserved cortical thickness and brain volume in middle-aged ${ }^{11,12}$ and older individuals, ${ }^{13-15}$ especially in brain regions associated with aging and Alzheimer disease $(\mathrm{AD})$. Moreover, adherence to MeDi has been related to lower amyloid load studied with ${ }^{11} \mathrm{C}$-Pittsburgh compound B-PET in cognitively unimpaired individuals, ${ }^{11,16,17}$ while another study could not find such an association using ${ }^{18} \mathrm{~F}$-florbetaben-PET. ${ }^{18}$ Furthermore, 1 study found an association in volunteers with subjective cognitive decline (SCD) or MCI between MeDi and lower FDDNP-PET, a compound measure of amyloid and tau pathology. ${ }^{19}$ Two longitudinal studies reported better $\mathrm{MeDi}$ adherence to be associated with less amyloid accumulation over time. ${ }^{17,20}$

This initial evidence suggests that MeDi might reduce amyloid deposition since midlife with a probable downstream effect on neurodegeneration and cognition. We in addition hypothesized that $\mathrm{MeDi}$ is associated with tau levels and moderates the associations among amyloid, tau, and brain atrophy. Here, we examined these questions by leveraging a large cohort of older individuals at increased risk for $\mathrm{AD}$.

\section{Methods}

\section{Standard Protocol Approvals, Registrations, and Patient Consents}

At each DZNE-Longitudinal Cognitive Impairment and Dementia Study (DELCODE) site, the local institutional review boards approved the study protocol, and the ethics committees issued local ethics approval. DELCODE is registered at the German Clinical Trials Register (DRKS00007966; April 5 , 2015). The study protocol followed the ethics principles for human experimentation in accordance with the Declaration of Helsinki. All participants in the study provided written informed consent.

\section{Participants}

As of July 2020, the baseline of the German multicenter DELCODE includes 1,079 individuals. A complete overview of the study design, group definitions, and aims is provided in a previous paper. ${ }^{21}$ Here, we selected 512 individuals (average \pm SD age $69.49 \pm 5.86$ years, 270 female, self-reported sex) according to availability of both the detailed food frequency questionnaire (FFQ) and T1-weighted MRI. The sample was enriched for risk of $\mathrm{AD}$ in that it included individuals with $\operatorname{SCD}(\mathrm{n}=209,41 \%)$ or amnestic MCI $(\mathrm{n}=81,16 \%)$ who were referrals to the participating memory clinics. Participants with SCD reported self-perceived cognitive decline with concerns while showing a preserved performance in all tests of the Consortium to Establish a Registry for Alzheimer's Disease (CERAD) neuropsychological battery (above -1.5 SDs compared to age-, sex-, and education-adjusted norms). Conversely, individuals with amnestic MCI performed below -1.5 SDs on the delayed-recall trial of the CERAD word-list episodic memory tests. The clinical diagnoses were part of the clinical workup at each site (not of DELCODE itself) and conformed to published research criteria. ${ }^{22-24}$ In addition, first-degree relatives of patients with $\mathrm{AD}(\mathrm{n}=53,10 \%)$ and cognitively normal volunteers without increased risk for $\mathrm{AD}$ ( $\mathrm{n}=169,33 \%)$ were recruited with an advertisement campaign in local newspapers. Both groups met the requirement for an unimpaired cognitive performance on the CERAD battery (as the SCD group).

Complete demographic information is reported in table 1 and stratified by clinical group in table e-2, doi.org/10.5061/ dryad.6tlg1jwxg. A subsample of 226 participants in addition underwent lumbar puncture for assessment of $\mathrm{AD}$-related 
Table 1 Demographic and Basic Clinical Characteristics $(n=512)$

\begin{tabular}{|c|c|c|c|c|}
\hline Variables & Mean & SD & Min & Max \\
\hline Age, y & 69.49 & 5.86 & 59 & 86 \\
\hline Education, y & 14.57 & 2.91 & 8 & 20 \\
\hline MMSE score, range $0-30$ & 29.10 & 1.30 & 18 & 30 \\
\hline $\begin{array}{l}\text { CDR Sum of Boxes score, range } \\
0-18\end{array}$ & 0.43 & 0.86 & 0 & 7.5 \\
\hline $\mathrm{BMI}, \mathrm{kg} / \mathrm{m}^{2 a}$ & 25.76 & 3.83 & 16.00 & 47.00 \\
\hline Daily energy intake, kcal/d & $2,298.95$ & 743.26 & 765.10 & $4,954.60$ \\
\hline Physical activity score (PASE) ${ }^{a}$ & 31.10 & 11.95 & 4.67 & 78.75 \\
\hline $\begin{array}{l}\text { Mediterranean diet score, range } \\
0-9\end{array}$ & 4.53 & 1.64 & 0 & 8 \\
\hline \multirow[t]{2}{*}{ MEM score } & 0.31 & 0.7 & -2.2 & 3.83 \\
\hline & & \multicolumn{3}{|c|}{ Frequencies (\%) } \\
\hline F/M, n (\%) & & \multicolumn{3}{|c|}{$270 / 242(52.7 / 47.3)$} \\
\hline \multicolumn{2}{|l|}{ APOE \&4 carriers/noncarriers, $\mathrm{n}(\%)^{\mathrm{a}}$} & \multicolumn{3}{|c|}{$143 / 358(28.54 / 71.46)$} \\
\hline \multicolumn{5}{|l|}{ Cognitive status, $\mathrm{n}(\%)$} \\
\hline \multicolumn{2}{|l|}{ Cognitively normal } & \multicolumn{3}{|c|}{$431(84.2 \%)$} \\
\hline \multicolumn{2}{|l|}{$\mathrm{MCl}$} & \multicolumn{3}{|c|}{$81(15.8 \%)$} \\
\hline
\end{tabular}

Abbreviations: $\mathrm{BMI}=$ body mass index; $\mathrm{CDR}=$ Clinical Dementia Rating; Max = maximum; $\mathrm{MCl}$ = mild cognitive impairment; $\mathrm{MEM}=$ memory summary factor score; Min = minimum; MMSE = Mini-Mental State Examination; PASE $=$ Physical Activity Scale for the Elderly.

a Incomplete data: 508 cases for BMI, 504 for CDR, 494 for PASE, and 501 for $A P O E \& 4$ status.

neuropathologic biomarkers in CSF. Comparing the groups with and without CSF information, we did not find differences in age, sex distribution, prevalence of $A P O E \varepsilon 4$, body mass index (BMI; kilocalories per day), level of physical activity (as measured with the Physical Activity Scale for the Elderly), ${ }^{25}$ or MeDi score. However, individuals with CSF data available had a lower educational attainment, a higher prevalence of MCI, and accordingly a lower performance on the MiniMental State Examination (table e-1).

\section{MRI Acquisition}

The acquisition of structural brain images was performed with 3T MRI scanners mounting 32-channel head array coils. A 3D T1-weighted magnetization prepared rapid gradient echo sequence was used, with an echo time of 4.37 milliseconds, repetition time of 2,500 milliseconds, inversion time of 1,100 milliseconds, and flip angle of $7^{\circ}$. All images had a $1-\mathrm{mm}^{3}$ isotropic nominal image resolution with a final image matrix of $256 \times 256 \times 192$. Four different MRI scanners from Siemens (Siemens Healthcare, Erlangen, Germany) were used across centers: MAGNETOM TrioTim $(\mathrm{n}=209)$, Verio $(\mathrm{n}=$ $163)$, Skyra $(n=110)$, and Prisma $(n=30)$. Image quality assessment is described in the supplements (doi.org/10. 5061/dryad.6t1gljwxg).

\section{Cognitive Assessment}

All study participants underwent an in-depth neuropsychological assessment to cover a broad spectrum of cognitive functioning. ${ }^{21}$ Our analysis focused on 5 factor scores derived from a confirmatory factor analysis and capturing the cognitive performance in different domains: memory, language, executive functions, working memory, and visuospatial abilities. Rationale and methods for the definition of factor scores are described in a previous paper. ${ }^{26} \mathrm{~A}$ list of the cognitive tests contributing to each cognitive domain is given in table e-3, doi.org/10.5061/dryad.6t1gljwxg/.

\section{Dietary Assessment and MeDi Score Definition}

We administered the German adaptation of the semiquantitative European Prospective Investigation of Cancer (EPIC) $\mathrm{FFQ}^{27}$ (more details in supplements, doi.org/10. 5061/dryad.6t 1 gljwxg/). Our sample of 512 participants did not include those who reported abnormal daily energy intake, defined as $<500$ or $>5,000 \mathrm{kcal} / \mathrm{d}(\mathrm{n}=4)$ and individuals who did not answer more than $20 \%$ of the FFQ questions $(n=2)$.

We computed the a priori MeDi score on the basis of sexspecific medians from this study population. Briefly, food items from the EPIC-FFQ were clustered into 9 food categories. A score of 1 was assigned when the food intake for 1 participant was equal to or above the sex-specific median for 6 food categories typical of MeDi (fish, vegetables, fruits/nuts, legumes, cereals, and higher ratio of monounsaturated/ saturated fats) or below the cutoff for foods nontypical of $\mathrm{MeDi}$ (meat, dairy products). For alcohol, a moderate consumption ( $10-50 \mathrm{~g} / \mathrm{d}$ in men and $5-25 \mathrm{~g} / \mathrm{d}$ in women) was considered beneficial and scored 1 point. The final MeDi score can span from 0 to 9 , with higher values indicating higher adherence. ${ }^{28}$ Table e-4 and figure e-3 (doi.org/10. 5061/dryad.6t $1 \mathrm{gljwxg} /$ ) display each food category stratified by MeDi score (low, medium, high) and sex.

\section{CSF Sampling and Assessment}

A subsample of 226 participants consented to undergo lumbar puncture. All procedures were guided by German Center for Neurodegenerative Diseases standard operating procedures (see supplementary Methods, doi.org/10.5061/dryad. $6 t \operatorname{lgljwxg} /)$. We focused our analyses on phosphorylated tau 181 (pTau181), $\beta$-amyloid -42 $_{1-4}\left(\mathrm{~A} \beta_{42}\right)$, their ratio $\mathrm{A} \beta_{42} /$ pTau181, and the $A \beta_{42 / 40}$ ratio to take into account individual differences in overall $A \beta$ peptide concentrations. ${ }^{29}$

\section{Voxel-Based Morphometry Analysis}

We applied voxel-based morphometry ${ }^{30}$ to study the relationship between gray matter volume and MeDi. All analyses were performed with the Computational Anatomy Toolbox (CAT12) and Statistical Parametric Mapping (SPM12, Wellcome Trust Centre for Neuroimaging, University College London, UK) running on Matlab 2014b (The MathWorks, In., Natick, MA). All T1-MRI images were normalized to the Montreal Neurological Institute standard space and segmented into gray matter, white matter, and CSF 
A
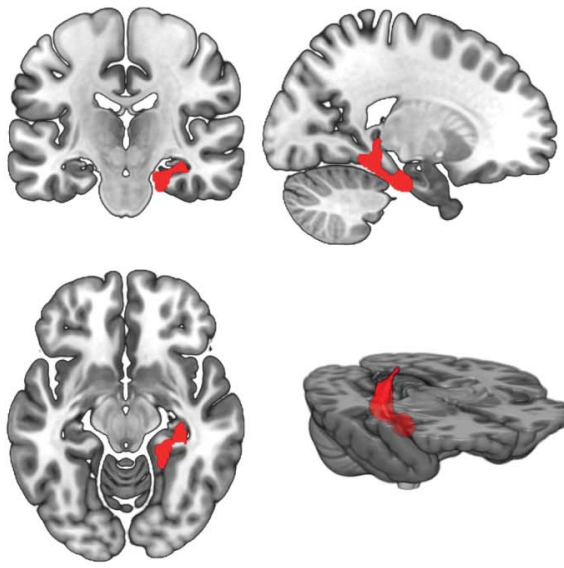

B
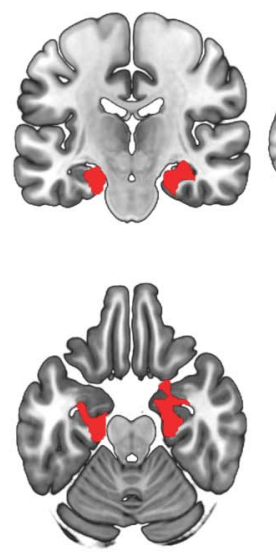

(A) Positive association between Mediterranean diet (MeDi) score and brain gray matter volume at the whole-brain level. (B) Positive association between MeDi score and gray matter volume in a priori-defined regions of interest (ROIs) covering the bilateral hippocampi and parahippocampal gyri. All results are corrected for age, sex, total intracranial volume, and MRI scanner heterogeneity. Results are shown at $p<0.05$ family-wise error corrected. Images are displayed in neurologic convention: left of the brain on the left of the image. Unthresholded $\mathrm{T}$ map is available at Neurovault (neurovault. org/collections/KMIELIOW/). compartments. Modulation of preprocessed MRI images included both linear and nonlinear deformations (i.e., jacobian determinants) to account for contractions and expansions during image normalization. Image smoothing was applied with a $8-\mathrm{mm}$ full width at half-maximum gaussian kernel. Total intracranial volume and total gray matter volume were extracted from CAT12 output.

The association between MeDi score and gray matter volume was investigated via application of the general linear model (1sample $t$ test in SPM12) with age, sex, total intracranial volume, and MRI scanner type entered as nuisance covariates. Heterogeneity in MRI devices was expressed with one-hot encoding for categorical data to avoid order effects. In addition, we reran the analysis correcting also for caloric intake, BMI, physical activity levels, and APOE \&4 status. The model was first applied at the whole-brain level, without any a priori hypothesis, and then restricted to hypothesis-driven regions of interest (ROIs) in the mediotemporal lobe, which shows early changes in $\mathrm{AD} .^{31}$ Anatomic ROIs were selected from the Automated Anatomical Labeling atlas using the Wake Forest University Pickatlas tool for SPM (bilateral hippocampi and parahippocampal gyri). Of note, the entorhinal cortex is included in the parahippocampal gyrus ROI as defined in the Automated Anatomical Labeling atlas (figure e-4, doi.org/10. 5061/dryad.6t1gljwxg/). Correction for multiple comparisons was performed with the nonparametric threshold free cluster enhancement approach implemented in SPM (neuro.uni-jena. $\mathrm{de} / \mathrm{tfce} /)$. We used the threshold free cluster enhancement technique with 5,000 permutations, weighting parameters for cluster extent $\mathrm{E}=0.6$ and height $\mathrm{H}=2$ and a significance level of $p<0.05$ (family-wise error [FWE] corrected).

\section{Statistical Analysis on CSF Variables and Cognitive Factors}

We assessed the associations between $\mathrm{MeDi}$ and cognition or CSF variables with linear regression models adjusted for age, sex, and education. The analysis was repeated including supplementary covariates to control for potential confounding effects from BMI, caloric intake, and physical activity, as well as for $A P O E \& 4$. Outliers identified on CSF variables were removed from the analysis, leading to the exclusion of 12 individuals who had values at 1.5 multiplied by the interquartile range below or above the 25 th or the 75 th percentile, respectively. Figure e-2, doi.org/10.5061/dryad.6t1g1jwxg/, displays the distributions of CSF variables. We repeated the analysis without outlier exclusion (applying log transformation to pTau181) and with robust linear regression, which is less sensitive to outliers. Finally, all linear models were corrected for the time distance between baseline visit (when biomarkers and cognitive assessment took place) and FFQ questionnaire (mean \pm SD $41.5 \pm 43.17$ weeks, median 51.7 weeks).

\section{Mediation Analysis}

We created hypothesis-driven models and tested them with mediation and moderated mediation analysis. All models were created with processR and estimated with the lavaan package (version 0.6-5, lavaan.ugent.be/) in $\mathrm{R}$ version 3.6 .3 ( $\mathrm{R}$ Foundation for Statistical Computing, Vienna, Austria).

The aim of model 1 was to investigate the interplay among $\mathrm{MeDi}$, brain volume, and memory function. Specifically, we hypothesized that the brain changes observed in the bilateral hippocampi and parahippocampal regions mediate the association between $\mathrm{MeDi}$ and memory identified in the regression analyses (figure 2). The model included all the 512 individuals in the study. Gray matter values were extracted from the significant cluster from the ROI-based analysis using MarsBaR toolbox for SPM. To assess the specificity of the mediation effect for mediotemporal regions, we replicated a similar mediation model using total gray matter volume as mediator. A parameter to model the indirect effects of $\mathrm{MeDi}$ on memory via brain measures was included. 


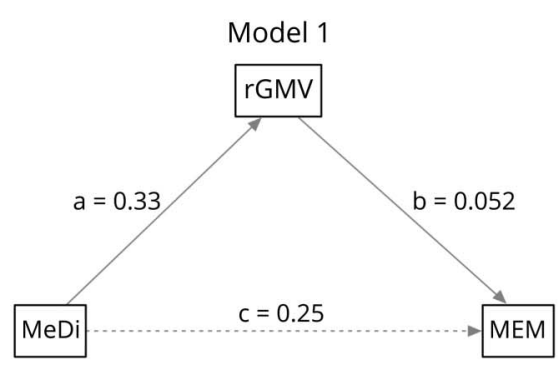

Model 2.1
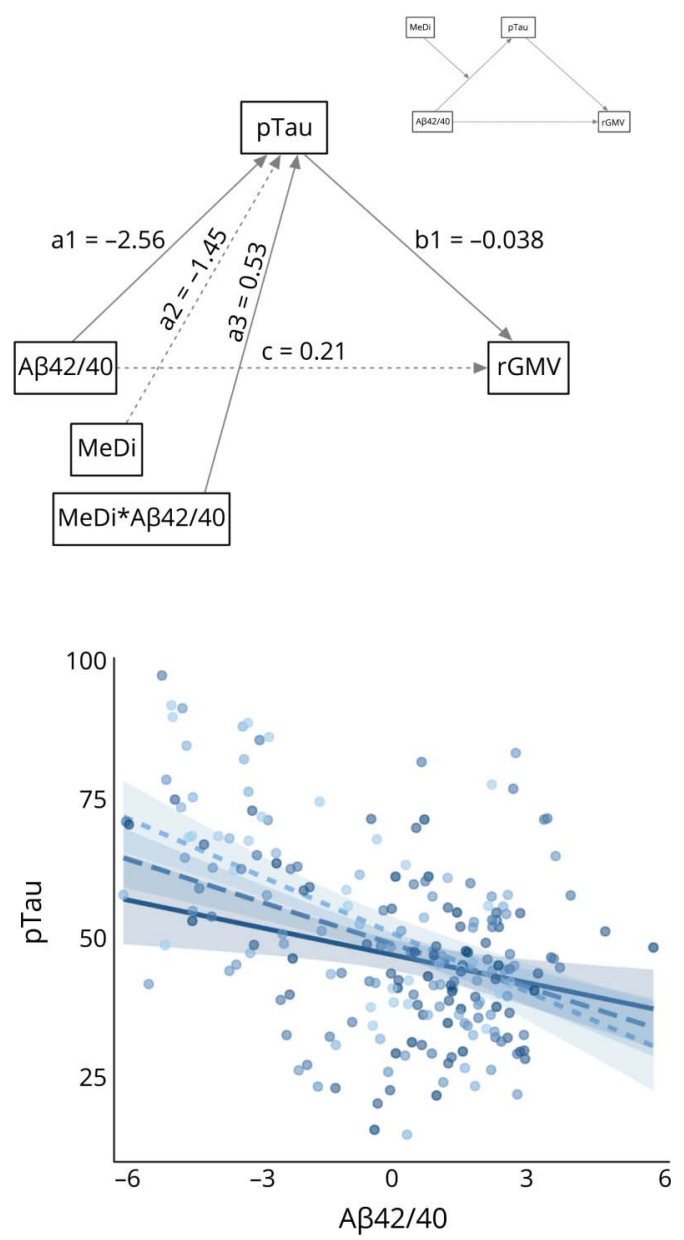

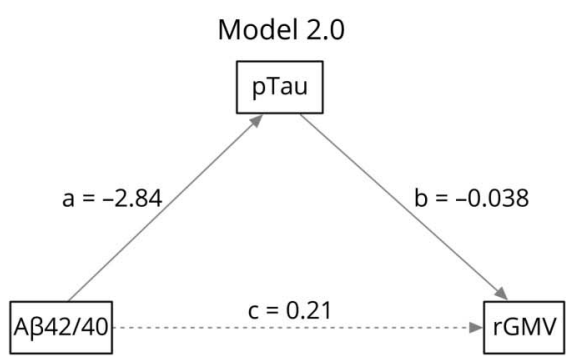

Model 2.2
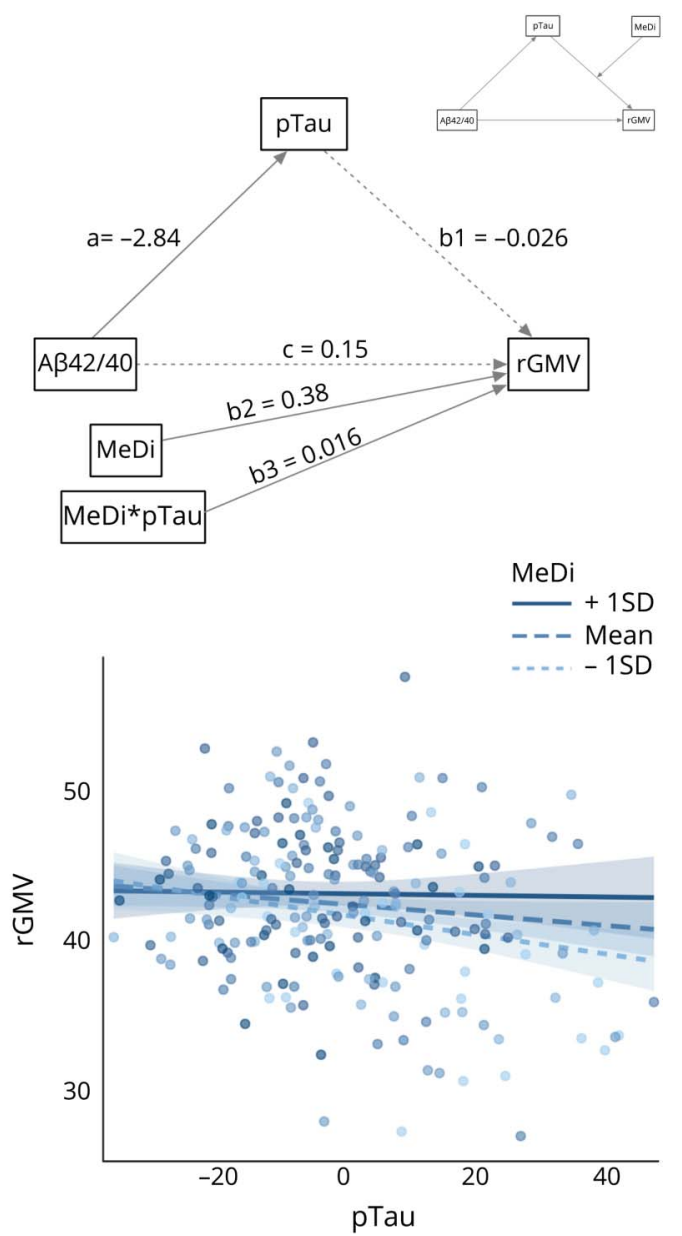

Names of the paths and associated regression estimates are reported. Solid lines represent significant paths according to confidence intervals generated with bias corrected bootstrap with 10,000 replicates. Dashed lines mark nonsignificant regression paths. For models 2.1 and 2.2 , in addition to the statistical models, the conceptual models are shown in the upper right corners, and simple slopes representing the interactions effects are shown below. A complete overview of direct and indirect effects is reported in table $4 . A \beta_{42 / 40}=$ ratio between $\beta$-amyloid 42 and $\beta$-amyloid $40 ; M e D i=M e d i t e r r a n e a n$ diet; $M E M=$ memory summary factor score; pTau = phosphorylated tau; rGMV = regional gray matter volume in bilateral hippocampi and parahippocampi.

We then designed additional models to disentangle the moderation effect of $\mathrm{MeDi}$ on the associations between $\mathrm{A} \beta_{42 / 40}$ ratio and pTau181 and brain volume in mediotemporal regions. In particular, we adopted the theoretical framework of the amyloid cascade hypothesis according to which amyloidosis is the earliest upstream pathologic event that leads to tau phosphorylation and finally to brain atrophy. ${ }^{32}$ The following models were therefore performed on the subsample with CSF information. The rationale for these models is that MeDi adherence might sustain brain maintenance, thus reducing the development of disease-related brain changes and pathology. ${ }^{33}$ In particular, we expected that MeDi moderates the paths connecting neuropathology and brain atrophy as defined by the amyloid cascade model. First, we tested a mediation model reflecting the amyloid cascade hypothesis itself, ie, $\mathrm{A} \beta_{42 / 40} \rightarrow$ pTau181 $\rightarrow$ brain volume (model 2.0). Then, we tested 2 additional models in which MeDi score was added as a moderator either of the 
Table 2 Montreal Neurological Institute Coordinates and Statistics From Neuroimaging Analysis

\begin{tabular}{|c|c|c|c|c|c|}
\hline $\mathrm{K}_{\mathrm{E}}$ & $p$ Value (FWE) & $p$ Value (FDR) & TFCE & $p$ Value (unc) & $x z y$ \\
\hline \multicolumn{6}{|c|}{ Whole-brain results } \\
\hline \multirow[t]{3}{*}{1,339} & 0.032 & 0.043 & $2,747.53$ & 0.001 & $22-39-14$ \\
\hline & 0.035 & 0.043 & $2,676.16$ & 0.001 & $22-32-21$ \\
\hline & 0.036 & 0.043 & $2,670.39$ & 0.002 & $22-21-24$ \\
\hline \multicolumn{6}{|c|}{ ROI-based results } \\
\hline \multirow[t]{3}{*}{2,343} & 0.004 & 0.007 & 841.96 & $<0.001$ & $22-38-12$ \\
\hline & 0.006 & 0.007 & 774.82 & $<0.001$ & $38-30-14$ \\
\hline & 0.006 & 0.007 & 772.33 & $<0.001$ & $22-21-24$ \\
\hline \multirow[t]{3}{*}{1,366} & 0.011 & 0.007 & 644.53 & 0.001 & $-20-21-26$ \\
\hline & 0.026 & 0.008 & 489.51 & 0.002 & $-18-9-12$ \\
\hline & 0.027 & 0.008 & 483.28 & 0.003 & $-30-9-16$ \\
\hline
\end{tabular}

Abbreviations: $F D R=$ false discovery rate; FWE = family-wise error rate; $\mathrm{K}_{\mathrm{E}}=$ equivalent cluster size; $\mathrm{ROI}$ = region of interest; TFCE = threshold free cluster enhancement value; unc = uncorrected.

path connecting $A \beta_{42 / 40}$ to pTau181 (model 2.1, first-stage mediation) or of the path connecting pTau181 to brain volume (model 2.2, second-stage mediation). This analysis allows us to test whether the associations between $A \beta_{42 / 40}$ and pTau 181 and between pTau 181 and brain volume vary at different levels of MeDi. A schematic visualization of the models is presented in figure 2.

In all models, we included age, sex, and education level as background confounds, and brain measures were also corrected for total intracranial volume. In addition, we tested the influence of $A P O E \& 4$ as a covariate. The significance of the associations was based on confidence intervals (CIs) generated with bias corrected bootstrap with 10000 replicates. In the moderated mediation models, all predictors were mean centered. For models 2.1 and 2.2, direct and indirect effects were evaluated at different levels of the moderator (i.e., $\mathrm{MeDi}$ ) using the mean $\pm 1 \mathrm{SD}$ approach. In addition, we report the index of moderated mediation, which reflects whether the indirect effects vary at different levels of the moderator.

\section{Exploratory Analysis of MeDi Diet Components}

To explore the individual contribution of each of the $9 \mathrm{MeDi}$ score components, we ran additional linear regression models. Dependent variables were the memory factor score, brain volume in hippocampal and parahippocampal regions, pTau181, or $A \beta_{42 / 40}$ ratio. In each model, we entered all dichotomous $\mathrm{MeDi}$ components at once, correcting for age, sex, education, caloric intake, BMI, and physical activity.

\section{Data Availability}

Anonymized data generated and analyzed in the current study will be made available on reasonable request from qualified investigators.

\section{Results}

\section{Brain Volume}

\section{Whole-Brain Results}

The MeDi score showed a significant positive association with brain gray matter volume in the right parahippocampal gyrus and right hippocampus ( $p<0.05$ FWE corrected). The opposite contrast did not show any negative association. Results are shown in figure 1A and in table 2. Figure e-1 (doi.org/10. 5061/dryad.6tlg1jwxg/) shows the results corrected with the less conservative $p<0.05$ false discovery rate approach.

\section{ROI-Based Results}

Restricting the analysis to a priori ROIs revealed a bilateral association between higher $\mathrm{MeDi}$ and increased gray matter volume in hippocampi and parahippocampal gyri $(p<0.05$ FWE corrected). Of note, we observed also in this analysis a right $>$ left asymmetry (figure $1 \mathrm{~B}$ and table 2 ). The opposite contrast did not reveal any negative association. Of note, a 1-point increase in $\mathrm{MeDi}$ corresponds to an increase in brain volume in the significant cluster associated with -0.84 years of age. The results of whole-brain and ROI-based analyses were stable correcting for caloric intake, BMI, physical activity, and $A P O E \& 4$ status. The unthresholded $\mathrm{T}$ maps of whole-brain models are available at Neurovault (neurovault.org/collections/KMIELIOW/).

\section{Cognition}

The models adjusted for age, sex, and education showed an association between $\mathrm{MeDi}$ and both memory $\left(F_{4,507}=57.87\right.$, $\left.p<0.001, R^{2}=0.31\right)$ and language $\left(F_{4,507}=59.22, p<0.001\right.$, $R^{2}=0.32$ ) but not for the other domains (table 3 ). In the models also corrected for BMI, caloric intake, and physical activity, only the association between an increased adherence 
Table 3 Associations Among MeDi Score, Cognitive Outcomes, and CSF Biomarkers

\begin{tabular}{|c|c|c|c|c|c|}
\hline & Model & Estimate & $\begin{array}{l}\text { Standard } \\
\text { error }\end{array}$ & $\mathrm{Cl}$ & $\begin{array}{l}p \\
\text { Value }\end{array}$ \\
\hline \multirow[t]{4}{*}{ Memory } & 1 & 0.05 & 0.02 & 0.01 to 0.08 & $0.005^{a}$ \\
\hline & 2 & 0.03 & 0.02 & 0.00 to 0.07 & $0.038^{a}$ \\
\hline & $1+A P O E$ & 0.04 & 0.02 & 0.01 to 0.07 & $0.007^{a}$ \\
\hline & $2+A P O E$ & 0.04 & 0.02 & 0.00 to 0.07 & $0.031^{a}$ \\
\hline \multirow[t]{4}{*}{ Language } & 1 & 0.03 & 0.02 & 0.00 to 0.06 & $0.027^{a}$ \\
\hline & 2 & 0.02 & 0.02 & -0.01 to 0.05 & 0.261 \\
\hline & $1+A P O E$ & 0.03 & 0.02 & -0.00 to 0.06 & 0.055 \\
\hline & $2+A P O E$ & 0.02 & 0.02 & -0.01 to 0.05 & 0.291 \\
\hline \multirow{4}{*}{$\begin{array}{l}\text { Executive } \\
\text { functions }\end{array}$} & 1 & 0.01 & 0.02 & -0.02 to 0.04 & 0.510 \\
\hline & 2 & 0.00 & 0.02 & -0.03 to 0.04 & 0.866 \\
\hline & $1+A P O E$ & 0.01 & 0.02 & -0.02 to 0.04 & 0.561 \\
\hline & $2+A P O E$ & 0.00 & 0.02 & -0.03 to 0.04 & 0.837 \\
\hline \multirow{4}{*}{$\begin{array}{l}\text { Working } \\
\text { memory }\end{array}$} & 1 & 0.02 & 0.02 & -0.01 to 0.05 & 0.254 \\
\hline & 2 & 0.02 & 0.02 & -0.02 to 0.05 & 0.317 \\
\hline & $1+A P O E$ & 0.02 & 0.02 & -0.02 to 0.05 & 0.327 \\
\hline & $2+A P O E$ & 0.02 & 0.02 & -0.02 to 0.05 & 0.337 \\
\hline \multirow{4}{*}{$\begin{array}{l}\text { Visuospatial } \\
\text { abilities }\end{array}$} & 1 & 0.02 & 0.02 & -0.01 to 0.05 & 0.241 \\
\hline & 2 & 0.01 & 0.02 & -0.02 to 0.04 & 0.482 \\
\hline & $1+A P O E$ & 0.02 & 0.02 & -0.02 to 0.05 & 0.339 \\
\hline & $2+A P O E$ & 0.01 & 0.02 & -0.02 to 0.04 & 0.543 \\
\hline \multirow[t]{4}{*}{ pTau181 } & 1 & -2.26 & 0.65 & $\begin{array}{l}-3.54 \text { to } \\
-0.99\end{array}$ & $<0.001^{a}$ \\
\hline & 2 & -1.96 & 0.68 & $\begin{array}{l}-3.29 \text { to } \\
-0.63\end{array}$ & $0.004^{a}$ \\
\hline & $1+A P O E$ & -1.89 & 0.64 & $\begin{array}{l}-3.15 \text { to } \\
-0.62\end{array}$ & $0.004^{a}$ \\
\hline & $2+A P O E$ & -1.64 & 0.67 & $\begin{array}{l}-2.96 \text { to } \\
-0.33\end{array}$ & $0.015^{a}$ \\
\hline \multirow[t]{4}{*}{$A \beta_{42}$} & 1 & 24.24 & 12.00 & 0.58 to 47.90 & $0.045^{a}$ \\
\hline & 2 & 17.77 & 12.45 & $\begin{array}{l}-6.79 \text { to } \\
42.33\end{array}$ & 0.155 \\
\hline & $1+A P O E$ & 12.58 & 11.54 & $\begin{array}{l}-10.17 \text { to } \\
35.33\end{array}$ & 0.277 \\
\hline & $2+A P O E$ & 8.16 & 11.93 & $\begin{array}{l}-15.36 \text { to } \\
31.68\end{array}$ & 0.494 \\
\hline \multirow[t]{3}{*}{$A \beta_{42 / 40}$} & 1 & 0.0034 & 0.00098 & 0.00 to 0.01 & $0.001^{a}$ \\
\hline & 2 & 0.0027 & 0.001 & 0.00 to 0.00 & $0.008^{a}$ \\
\hline & $1+A P O E$ & 0.0022 & 0.0009 & $\begin{array}{l}0.0004 \text { to } \\
0.0039\end{array}$ & $0.014^{a}$ \\
\hline
\end{tabular}

Table 3 Associations Among MeDi Score, Cognitive Outcomes, and CSF Biomarkers (continued)

\begin{tabular}{|c|c|c|c|c|c|}
\hline & Model & Estimate & $\begin{array}{l}\text { Standard } \\
\text { error }\end{array}$ & $\mathrm{Cl}$ & $\begin{array}{l}p \\
\text { Value }\end{array}$ \\
\hline & $2+A P O E$ & 0.0017 & 0.0009 & $\begin{array}{l}-0.0001 \text { to } \\
0.0035\end{array}$ & 0.064 \\
\hline \multirow{4}{*}{$\begin{array}{l}\mathrm{A} \beta_{42} / \\
\text { pTau181 }\end{array}$} & 1 & 0.94 & 0.26 & 0.43 to 1.45 & $<0.001^{a}$ \\
\hline & 2 & 0.71 & 0.27 & 0.18 to 1.24 & $0.009^{a}$ \\
\hline & $1+A P O E$ & 0.63 & 0.24 & 0.16 to 1.09 & $0.009^{a}$ \\
\hline & $2+A P O E$ & 0.46 & 0.25 & -0.03 to 0.94 & 0.063 \\
\hline
\end{tabular}

Abbreviations: $A \beta=\beta$-amyloid; $C I=$ confidence interval; $M e D i=$ Mediterranean diet; pTau181 = phosphorylated tau 181 .

Results of linear regression models. Covariates in model 1: age, sex, years of education. Covariates in model 2: age, sex, years of education, body mass index, total daily caloric intake, and level of physical activity. Model 1 and 2 $+A P O E \varepsilon 4$ show the results after additional correction for APOE \&4 status (carriers or noncarriers).

a Significant.

to $\mathrm{MeDi}$ and an improved memory performance remained $\left(F_{7,482}=30.57, p<0.001, R^{2}=0.31\right)$. Here, a 1-point increase of $\mathrm{MeDi}$ corresponded to an increase of memory performance associated with almost -1 year of age. Correcting for APOE $\varepsilon 4$ and time distance between baseline visit and FFQ did not change the results (table 3 and table e-7, doi.org/10.5061/ dryad.6tlg1jwxg/).

\section{CSF Biomarkers}

The linear regression models showed significant associations of MeDi with pTau181 $\left(F_{4,209}=6.02, p<0.001, R^{2}=0.103\right)$, $\mathrm{A} \beta_{42 / 40}\left(F_{4,209}=6.15, p<0.001, R^{2}=0.105\right)$ and $\mathrm{A} \beta_{42} /$ pTau181 $\left(F_{4,209}=6.29, p<0.001, R^{2}=0.107\right)$.

The associations of MeDi with pTau181 $\left(F_{7,197}=4.118, p<\right.$ $\left.0.001, R^{2}=0.128\right), \mathrm{A} \beta_{42 / 40}\left(F_{7,197}=3.509, p=0.0014, R^{2}=\right.$ $0.111)$, and $\mathrm{A} \beta_{42} / \mathrm{pTau} 181\left(F_{7,197}=3.933, p<0.001, R^{2}=\right.$ 0.123 ) were stable in addition controlling for BMI, caloric intake, and physical activity (table 3 ). Higher adherence to MeDi showed associations with $p$ Tau181 and both $A \beta_{42 / 40}$ and $A \beta_{42} /$ pTaul81 ratios. Specifically, in the adjusted models, a unity increase in $\mathrm{MeDi}$ score was associated with a decrease of $1.96 \mathrm{pg} / \mathrm{mL}$ in $\mathrm{pTau} 181$ and with an increase of 0.0027 and 0.71 in $A \beta_{42 / 40}$ and $A \beta_{42} / \mathrm{pT}$ Tau181 ratios, respectively. For comparison, a 1-point increase in $\mathrm{MeDi}$ corresponded to a decrease of the neuropathologic burden on $A \beta_{42 / 40}$ and pTau181 associated with $>-3$ years of age $(-3.5$ and -3.33 years, respectively). Correcting for $A P O E$ $\varepsilon 4$ reduced the associations between $\mathrm{MeDi}$ and CSF biomarkers for amyloid (but showing a consistent pattern of results, table 3), while the time distance between baseline visit and FFQ did not influence the results (table e-7, doi. org/10.5061/dryad.6tlg1jwxg/). We observed very similar results in the analysis without outlier exclusion and using 
Table 4 Result of Mediation and Moderated-Mediation Models

\begin{tabular}{|c|c|c|c|c|c|}
\hline & \multirow[b]{2}{*}{ Effect } & \multirow[b]{2}{*}{ Estimate } & \multirow[b]{2}{*}{ 95\% Bootstrap Cl } & \multicolumn{2}{|c|}{ Controlling for $A P O E \varepsilon 4$ Status } \\
\hline & & & & Estimate & 95\% Bootstrap Cl \\
\hline \multirow[t]{4}{*}{ Model 1} & Indirect & 0.017 & 0.007 to $0.030^{a}$ & 0.016 & 0.006 to $0.028^{a}$ \\
\hline & Direct & 0.025 & -0.005 to 0.056 & 0.024 & -0.006 to 0.054 \\
\hline & Total & 0.042 & 0.009 to $0.075^{a}$ & 0.040 & 0.008 to $0.073^{a}$ \\
\hline & Percent & $40 \%$ & & $40 \%$ & \\
\hline \multirow[t]{4}{*}{ Model 2.0} & Indirect & 0.109 & 0.009 to $0.239^{a}$ & 0.116 & 0.025 to $0.249^{a}$ \\
\hline & Direct & 0.210 & -0.070 to 0.471 & 0.195 & -0.094 to 0.473 \\
\hline & Total & 0.319 & 0.071 to $0.562^{a}$ & 0.311 & 0.048 to $0.580^{a}$ \\
\hline & Percent & $34 \%$ & & $37 \%$ & \\
\hline \multicolumn{6}{|l|}{ Model 2.1} \\
\hline \multirow[t]{2}{*}{ Below } & Indirect & 0.133 & 0.011 to $0.308^{a}$ & 0.142 & 0.030 to $0.314^{a}$ \\
\hline & Percent & $39 \%$ & & $42 \%$ & \\
\hline \multirow[t]{2}{*}{ Mean } & Indirect & 0.098 & 0.010 to $0.220^{a}$ & 0.105 & 0.024 to $0.229^{a}$ \\
\hline & Percent & $32 \%$ & & $35 \%$ & \\
\hline \multirow[t]{3}{*}{ Above } & Indirect & 0.063 & 0.008 to $0.172^{a}$ & 0.068 & 0.010 to $0.180^{a}$ \\
\hline & Percent & $23 \%$ & & $26 \%$ & \\
\hline & IMM & -0.020 & -0.065 to $-0.001^{a}$ & -0.022 & -0.065 to $-0.001^{a}$ \\
\hline
\end{tabular}

Model 2.2

\begin{tabular}{|c|c|c|c|c|c|}
\hline Below & Indirect & 0.154 & 0.044 to $0.292^{a}$ & 0.164 & 0.068 to $0.306^{a}$ \\
\hline & Percent & $51 \%$ & & $54 \%$ & \\
\hline \multirow[t]{2}{*}{ Mean } & Indirect & 0.075 & -0.029 to 0.205 & 0.083 & -0.008 to 0.214 \\
\hline & Percent & $34 \%$ & & $37 \%$ & \\
\hline \multirow[t]{3}{*}{ Above } & Indirect & -0.005 & -0.159 to 0.160 & 0.002 & -0.142 to 0.160 \\
\hline & Percent & $3 \%$ & & $1 \%$ & \\
\hline & IMM & -0.047 & -0.101 to $-0.004^{a}$ & -0.048 & -0.101 to $-0.009^{a}$ \\
\hline
\end{tabular}

Abbreviations: $\mathrm{Cl}$ = confidence interval; IMM = index moderated mediation.

Percent indicates proportion of mediated effect. Effects for the moderated mediation models are shown at different levels of the moderator. Mean: at mean level of MeDi; below and above: at -1 and +1 standard deviations from the mean of MeDi, respectively.

a Significant paths according to Cls generated with bias corrected bootstrap with 10,000 replicates.

both linear and robust linear regressions (table e-5, doi.org/ $10.5061 /$ dryad.6tlgljwxg/).

\section{Mediation Models}

Model 1 revealed a significant indirect effect of $\mathrm{MeDi}$ on memory via brain volume in hippocampal and parahippocampal regions (effect estimate (est) 0.017, CI $0.007-0.03)$. Notably, the direct effect of MeDi on memory was no longer significant (est $0.025, \mathrm{CI}-0.005$ to 0.056 ), thus suggesting complete mediation. The indirect pathway representing the effect of $\mathrm{MeDi}$ on memory via hippocampal and parahippocampal volume accounted for $40 \%$ of the total effect. The replication of model 1 using total gray matter volume showed a significant direct effect, while the indirect effect was weak and accounted for only $4.6 \%$ of the total effect (table e-6, doi.org/10.5061/dryad.6t1g1jwxg/).

Model 2.0 showed a complete mediation of $A \beta_{42 / 40}$ on brain volume through pTau181 in that only the indirect effect (est 0.109 , CI $0.009-0.0239$ ) was significant and explained $34 \%$ of the total effect. In model 2.1, we observed a significant index of moderated mediation (est $-0.02, \mathrm{CI}-0.065$ to -0.001 ) and significant indirect effects at all levels of the moderator. The indirect effect was larger for lower values of $\mathrm{MeDi}$ and 
decreased for higher MeDi score. The proportion of the total effect mediated by the $\mathrm{A} \beta_{42 / 40} \rightarrow$ pTaul $181 \rightarrow$ brain volume path at different levels of MeDi was 39\% at -1 SD, 32\% at the mean level, and $23 \%$ at +1 SD. Model 2.2 showed a significant index of moderated mediation (est -0.047 , CI -0.101 to -0.004 ) and a significant indirect effect only at the lowest level of the moderator, ie, at $-1 \mathrm{SD}$. Complete details are displayed in table 4. All mediation and moderated-mediation models showed consistent results when corrected for APOE $\varepsilon 4$ (table 4).

\section{Individual Contributions of MeDi Components}

Table e-9 (doi.org/10.5061/dryad.6t1g1jwxg/) displays the results of the exploratory analysis on individual $\mathrm{MeDi}$ components. With memory function as a dependent variable, we observed a significant positive association only for cereals $(p=$ 0.013 ). Congruently, only cereals showed a marginally significant positive association with mediotemporal volume $(p=$ 0.056). For both pTau181 and $A \beta_{42 / 40}$ ratio, a significant association was found with the ratio of monounsaturated/ saturated fat ( $p=0.021$ and $p=0.038$, respectively). Specifically, an increased ratio of monounsaturated/saturated fat was associated with increased levels of $A \beta_{42 / 40}$ and decreased burden of pTau181.

\section{Discussion}

Overall, our results suggest that the favorable association between $\mathrm{MeDi}$ adherence and memory performance, found here as in many previous studies, could be mediated by preservation of brain volume in mediotemporal regions. Moreover, we show that $\mathrm{MeDi}$ adherence is inversely associated with both pathologic biomarkers for amyloidosis and tauopathy, which underlie AD. Finally, our data show that a healthier diet moderates the associations among $A \beta_{42 / 40}$, pTau181, and brain atrophy, suggesting that MeDi contributes to brain maintenance. ${ }^{33}$

First, we observed a significant association between $\mathrm{MeDi}$ and hippocampal and parahippocampal regions in both wholebrain and ROI-based analyses. This is in line with studies that reported positive associations between $\mathrm{MeDi}$ and brain morphology in cognitively normal middle- and old-aged individuals and in elderly individuals without dementia. ${ }^{11-15}$ However, 1 study reported no significant association between $\mathrm{MeDi}$ and brain volume, ${ }^{34}$ and another reported an association only with meat consumption but not with MeDi as a whole. ${ }^{35}$ Compared to these studies, we analyzed a larger sample enriched for $\mathrm{AD}$ risk, thus possibly making our analysis more sensitive to capture brain structural variations related to $\mathrm{MeDi}$. Moreover, in both negative studies, there was a larger temporal distance between dietary and MRI data assessments (5 and 9 years), which might have influenced the results. Several hypotheses could be advanced concerning the link between diet and brain structural integrity. Considering our moderated mediation results, we hypothesize that the adherence to $\mathrm{MeDi}$ protects brain structures from the adverse effects of upstream pathologic events, i.e., accumulation of amyloid plaques and tau phosphorylation. This hypothesis would clarify why the association between $\mathrm{MeDi}$ and brain structure is specific for the mediotemporal regions: $\mathrm{AD}$ related atrophy starts in these regions and colocalizes with tau accumulation.

The second main finding is the favorable association between $\mathrm{MeDi}$ and memory performance. In particular, we show a significant positive association between diet and a composite memory factor score, which, capitalizing on an in-depth memory assessment, was used to quantify the level of memory performance in our sample. ${ }^{26}$ This finding replicates previous work performed on a smaller interim release of DELCODE ${ }^{36}$ and is in agreement with the view of $\mathrm{MeDi}$ as a protective lifestyle factor against cognitive decline and dementia. ${ }^{1-3}$ Despite a protective effect of MeDi being reported for general cognition and for different cognitive domains, memory seems to be the one that benefits more from a healthy diet, ${ }^{15,37,38}$ in line with the region-specific association with brain volume. The analysis of the individual MeDi score components showed a significant association between memory and cereals. This supports previous studies showing a protective effect of cereals, in particular whole grains, on cognition. ${ }^{37,39} \mathrm{We}$ propose that the specificity of our findings for the memory domain should be interpreted in light of the mediation analysis showing that the mediotemporal volume mediates the association between $\mathrm{MeDi}$ and memory. Of note, the mediation effect was specific for the mediotemporal regions in that the mediating effect of total gray matter volume was very weak.

Finally, the analysis of the subsample with CSF information allowed us to investigate the associations between $\mathrm{MeDi}$ and $\mathrm{AD}$-related biomarkers and to model their interplay with brain volume. First, we reported that $\mathrm{MeDi}$ is associated with lower levels of amyloid pathology as expressed by the $A \beta_{42 / 40}$ ratio and with reduced $\mathrm{pTau} 181$. In agreement with our observations, previous studies in middle- and old-aged, cognitively normal individuals reported that diet is associated with reduced amyloid pathology levels and amyloid accumulation as studied with ${ }^{11} \mathrm{C}$-Pittsburgh compound B-PET assessments. ${ }^{17,20}$ Of note, we observed a significant association between $\mathrm{MeDi}$ and $A \beta_{42 / 40}$ ratio but not with $A \beta_{42}$. Previous studies suggested that the $A \beta_{42 / 40}$ ratio is a more sensitive biomarker for $\mathrm{AD}$ compared to $\mathrm{A} \beta_{42} \cdot{ }^{29}$ Moreover, a recent study on a cell culture model of $\mathrm{AD}$ showed the relevance $A \beta_{42 / 40}$ ratio, but not total amyloid, as driver of tau pathology. ${ }^{40}$ The mediation model 2.0 is in line with the amyloid cascade hypothesis, showing a link among $A \beta_{42 / 40}$, pTau181, and brain atrophy. ${ }^{32}$ Then, in models 2.1 and 2.2 , we showed that $\mathrm{MeDi}$ exerts a significant moderation effect both on the association between $A \beta_{42 / 40}$ ratio and pTau181 and, to a lesser extent, on that between pTau181 levels and brain atrophy, specifically mitigating their associations. However, these models should be interpreted with caution because they rely on cross-sectional data and cannot therefore 
prove causal pathways. A possible (and speculative) mechanistic interpretation of these observations is that $\mathrm{MeDi}$ acts on the triggers that connect these pathologic events, e.g., inflammation ${ }^{41}$ and oxidative stress. ${ }^{42} \mathrm{MeDi}$ is indeed based on higher consumption of fruits and vegetables, whole grains, fish, and olive oil, which are known for their anti-inflammatory and antioxidant actions. ${ }^{43}$ Future studies could include markers for inflammation or oxidative stress to test more finegrained hypotheses concerning the underlying biological processes.

Notably, the exploratory analysis of the individual $\mathrm{MeDi}$ components showed a beneficial association between the ratio of monounsaturated/saturated fat and both pTau181 and $A \beta_{42 / 40}$ ratio. Monounsaturated fats are found in many food sources such as plant oils, nuts, seeds, and animal products, and a combination of them likely accounted for the total level in our study. In Mediterranean regions, higher scores of monounsaturated/saturated fat ratio most likely reflect higher consumption of extravirgin olive, which has been associated with reduced $\mathrm{AD}$ pathology in mice ${ }^{44}$ and with better cognitive performance in human participants in the PREDIMED trial. $^{8}$

A strength of the present study is the availability of multiple data types, which enabled the integration of dietary information, cognitive data, brain morphometry, and CSF biomarkers. This allowed us to model not only the associations between $\mathrm{MeDi}$ and the single variables of interest but also their interplay. Another strength is that the sample is enriched for $\mathrm{AD}$ risk. While this constrains generalization to the older population at large, it allows studying the interaction of diet with substantial variation of amyloid, tau, and brain neurodegeneration in a group who could be a target for nutritional intervention trials. We also repeated the regression models excluding individuals with MCI, the highest-risk clinical group. This showed a stable association of $\mathrm{MeDi}$ with mediotemporal brain volume but not with other outcomes, pTau 181, $\mathrm{A} \beta_{42 / 40}$ ratio, and memory (table e-10, doi.org/10. 5061/dryad.6t1g1jwxg/). This might indicate that the beneficial associations between $\mathrm{MeDi}$ and $\mathrm{AD}$-related biomarkers and cognition are more pronounced in the prodromal $\mathrm{AD}$ stages. However, these negative findings might also be attributable to reduced power in the subsample analysis and to lower variability in the outcomes.

A limitation of the present cross-sectional study is that it does not allow causal inference. However, MeDi scores are stable over years in older adults, even in the years before a diagnosis of incident dementia, ${ }^{1,45}$ and Wagner et $\mathrm{al}^{46}$ showed that the longitudinal trajectories of $\mathrm{MeDi}$ over 15 years are comparable between women who showed cognitive decline and those who did not in the Nurses' Health Study. Therefore, we posit that $\mathrm{MeDi}$ adherence reflects the past aggregate exposure to the $\mathrm{MeDi}$ ingredients, so the statistical associations with $\mathrm{MeDi}$ described above could result from accumulated long-term causal effects of diet. The extension to longitudinal data, including data from DELCODE follow-ups, should be the next step to address this limitation and to validate the proposed models. Moreover, it has to be noted that the analysis of the single components presented here is exploratory and should be validated by more focused studies. Future studies in humans and animal models could focus on specific hypothesis-driven dietary components and leverage on modern techniques to directly measure their effects on the metabolome and microbiome. ${ }^{47}$ Along the same line, recent efforts to map the chemical complexity of diets provide a promising avenue for a deeper understanding of the effects of diet on health and disease. ${ }^{48}$ It has to be mentioned that previous studies reported an association between different dietary patterns (i.e., Western diet and the Alternative Healthy Eating Index 2010) and risk of dementia and cognitive decline ${ }^{49}$ or $\mathrm{AD}$-related markers such as hippocampal volume. ${ }^{5}$ This might bring into question whether the results reported in our study are specific for MeDi or rather reflect a more general advantage of a healthy diet. This is linked to another limitation of our and similar studies in which $\mathrm{MeDi}$ adherence is defined on sample medians, thus representing the relative adherence to dietary guidelines and not the high consumption of beneficial foods in absolute terms as in Mediterranean regions. Moreover, it is possible that $\mathrm{MeDi}$ has systemic effects on health (e.g., modulating inflammation or cardiovascular health ${ }^{50}$ ) that might in turn influence $\mathrm{AD}$ specific mechanisms. Our results were stable when we controlled for factors associated with cardiovascular risk (BMI, physical activity, and smoking, see table e-8, doi.org/10.5061/ dryad.6tlgljwxg/), but a deeper investigation of this topic is needed. The study of many other biomarkers such as diffusion tensor imaging, resting-state functional connectivity, and markers for neuroinflammation, especially in longitudinal study design, could help generate a more comprehensive and mechanistic understanding of the effects of $\mathrm{MeDi}$ on cognition in old age and early $\mathrm{AD}$.

Our study supports the view of $\mathrm{MeDi}$ as a protective lifestyle factor against $\mathrm{AD}$-related neurodegeneration and memory impairment. Longitudinal studies with $\mathrm{AD}$ biomarker outcomes could further examine this conjecture and pave the way for dietary interventions to delay $\mathrm{AD}$.

\section{Acknowledgment}

The authors thank all the participants of the DELCODE study for their contributions.

\section{Study Funding}

Study funded by the German Center for Neurodegenerative Diseases (Deutsches zentrum für Neurodegenerative Erkrankungen $[\mathrm{DZNE}])$ and by the Diet Body Brain research cluster funded by the German Federal Ministry of Education and Research (grant 01EA1809C).

\section{Disclosure}

T. Ballarini, D. Melo van Lent, J. Brunner, A. Schröder, S. Wolfsgruber, S. Altenstein, F. Brosseron, K. Buerger, P. 
Dechent, L. Dobisch, E. Düzel, B. Ertl-Wagner, K. Fliessbach, S. Dawn Freiesleben, I. Frommann, W. Glanz, D. Hauser, J. D. Haynes, M. T. Heneka, D. Janowitz, I. Kilimann, C. Laske, F. Maier, C. D. Metzger, M. H. Munk, R. Perneczky, and O. Peters report no disclosures relevant to the manuscript; J. Priller received fees for consultation, lectures, and patents from Neurimmune, Axon, Desitin, and Epomedics. A. Ramirez, B. Rauchmann, N. Roy, K. Scheffler, A. Schneider, A. Spottke, E. J. Spruth, S. Teipel, R. Vukovich, and J. Wiltfang report no disclosures relevant to the manuscript; F. Jessen received fees for consultation from Eli Lilly, Novartis, Roche, BioGene, MSD, Piramal, Janssen, and Lundbeck. M. Wagner reports no disclosures relevant to the manuscript. Go to Neurology.org/N for full disclosures.

\section{Publication History}

Received by Neurology August 6, 2020. Accepted in final form March 15, 2021.

\section{Appendix Authors}

\begin{tabular}{|c|c|c|}
\hline Name & Location & Contribution \\
\hline $\begin{array}{l}\text { Tommaso } \\
\text { Ballarini, } \\
\text { PhD }\end{array}$ & $\begin{array}{l}\text { German Center for } \\
\text { Neurodegenerative } \\
\text { Diseases (DZNE), Bonn, } \\
\text { Germany }\end{array}$ & $\begin{array}{l}\text { Conceptualization and } \\
\text { design of the study; } \\
\text { statistical analysis; } \\
\text { interpretation of data; } \\
\text { drafting and/or revision of } \\
\text { manuscript for important } \\
\text { intellectual content }\end{array}$ \\
\hline
\end{tabular}

\begin{tabular}{|c|c|c|}
\hline $\begin{array}{l}\text { Debora Melo } \\
\text { van Lent, } \\
\text { PhD }\end{array}$ & $\begin{array}{l}\text { DZNE, Bonn, Germany; } \\
\text { University of Texas Health } \\
\text { Science Center, San Antonio }\end{array}$ & $\begin{array}{l}\text { Conceptualization and } \\
\text { design of the study; drafting } \\
\text { and/or revision of } \\
\text { manuscript for important } \\
\text { intellectual content }\end{array}$ \\
\hline $\begin{array}{l}\text { Julia } \\
\text { Brunner, MSc }\end{array}$ & DZNE, Bonn, Germany & $\begin{array}{l}\text { Drafting and/or revision of } \\
\text { manuscript for important } \\
\text { intellectual content }\end{array}$ \\
\hline $\begin{array}{l}\text { Alina } \\
\text { Schröder, } \\
\text { MSc }\end{array}$ & DZNE, Bonn, Germany & $\begin{array}{l}\text { Drafting and/or revision of } \\
\text { manuscript for important } \\
\text { intellectual content }\end{array}$ \\
\hline $\begin{array}{l}\text { Steffen J. } \\
\text { Wolfsgruber, } \\
\text { PhD }\end{array}$ & DZNE, Bonn, Germany & $\begin{array}{l}\text { Drafting and/or revision of } \\
\text { manuscript for important } \\
\text { intellectual content }\end{array}$ \\
\hline $\begin{array}{l}\text { Slawek } \\
\text { Altenstein, } \\
\text { Dipl-Psych }\end{array}$ & DZNE, Berlin, Germany & $\begin{array}{l}\text { Drafting and/or revision of } \\
\text { manuscript for important } \\
\text { intellectual content }\end{array}$ \\
\hline $\begin{array}{l}\text { Frederic } \\
\text { Brosseron, } \\
\text { PhD }\end{array}$ & DZNE, Bonn, Germany & $\begin{array}{l}\text { Drafting and/or revision of } \\
\text { manuscript for important } \\
\text { intellectual content }\end{array}$ \\
\hline $\begin{array}{l}\text { Katharina } \\
\text { Buerger, MD }\end{array}$ & DZNE, Munich, Germany & $\begin{array}{l}\text { Drafting and/or revision of } \\
\text { manuscript for important } \\
\text { intellectual content }\end{array}$ \\
\hline $\begin{array}{l}\text { Peter } \\
\text { Dechent, } \\
\text { PhD }\end{array}$ & $\begin{array}{l}\text { Georg-August-University } \\
\text { Göttingen, Germany }\end{array}$ & $\begin{array}{l}\text { Drafting and/or revision of } \\
\text { manuscript for important } \\
\text { intellectual content }\end{array}$ \\
\hline $\begin{array}{l}\text { Laura } \\
\text { Dobisch, MSc }\end{array}$ & $\begin{array}{l}\text { DZNE, Magdeburg, } \\
\text { Germany }\end{array}$ & $\begin{array}{l}\text { Drafting and/or revision of } \\
\text { manuscript for important } \\
\text { intellectual content }\end{array}$ \\
\hline $\begin{array}{l}\text { Emrah Düzel, } \\
\text { MD }\end{array}$ & $\begin{array}{l}\text { DZNE, Magdeburg, } \\
\text { Germany }\end{array}$ & $\begin{array}{l}\text { Drafting and/or revision of } \\
\text { manuscript for important } \\
\text { intellectual content }\end{array}$ \\
\hline
\end{tabular}

Appendix (continued)

\begin{tabular}{|c|c|c|}
\hline Name & Location & Contribution \\
\hline $\begin{array}{l}\text { Birgit Ertl- } \\
\text { Wagner, MD }\end{array}$ & $\begin{array}{l}\text { Ludwig-Maximilians- } \\
\text { University, Munich, } \\
\text { Germany }\end{array}$ & $\begin{array}{l}\text { Drafting and/or revision of } \\
\text { manuscript for important } \\
\text { intellectual content }\end{array}$ \\
\hline $\begin{array}{l}\text { Klaus } \\
\text { Fliessbach, } \\
\text { MD }\end{array}$ & DZNE, Bonn, Germany & $\begin{array}{l}\text { Drafting and/or revision of } \\
\text { manuscript for important } \\
\text { intellectual content }\end{array}$ \\
\hline $\begin{array}{l}\text { Silka Dawn } \\
\text { Freiesleben, } \\
\text { MSc }\end{array}$ & Charité-Berlin, Germany & $\begin{array}{l}\text { Drafting and/or revision of } \\
\text { manuscript for important } \\
\text { intellectual content }\end{array}$ \\
\hline $\begin{array}{l}\text { Ingo } \\
\text { Frommann, } \\
\text { Dipl-Psych }\end{array}$ & DZNE, Bonn, Germany & $\begin{array}{l}\text { Drafting and/or revision of } \\
\text { manuscript for important } \\
\text { intellectual content }\end{array}$ \\
\hline $\begin{array}{l}\text { Wenzel } \\
\text { Glanz, MD }\end{array}$ & $\begin{array}{l}\text { DZNE, Magdeburg, } \\
\text { Germany }\end{array}$ & $\begin{array}{l}\text { Drafting and/or revision of } \\
\text { manuscript for important } \\
\text { intellectual content }\end{array}$ \\
\hline $\begin{array}{l}\text { Dietmar } \\
\text { Hauser, Dipl- } \\
\text { Psych }\end{array}$ & Charité-Berlin, Germany & $\begin{array}{l}\text { Drafting and/or revision of } \\
\text { manuscript for important } \\
\text { intellectual content }\end{array}$ \\
\hline $\begin{array}{l}\text { John Dylan } \\
\text { Haynes, PhD }\end{array}$ & $\begin{array}{l}\text { Bernstein Center for } \\
\text { Computational } \\
\text { Neuroscience, } \\
\text { Charité-Berlin, Germany }\end{array}$ & $\begin{array}{l}\text { Drafting and/or revision of } \\
\text { manuscript for important } \\
\text { intellectual content }\end{array}$ \\
\hline $\begin{array}{l}\text { Michael T. } \\
\text { Heneka, MD }\end{array}$ & DZNE, Bonn, Germany & $\begin{array}{l}\text { Drafting and/or revision of } \\
\text { manuscript for important } \\
\text { intellectual content }\end{array}$ \\
\hline $\begin{array}{l}\text { Daniel } \\
\text { Janowitz, MD }\end{array}$ & $\begin{array}{l}\text { Ludwig-Maximilians- } \\
\text { University, Munich, } \\
\text { Germany }\end{array}$ & $\begin{array}{l}\text { Drafting and/or revision of } \\
\text { manuscript for important } \\
\text { intellectual content }\end{array}$ \\
\hline $\begin{array}{l}\text { Ingo } \\
\text { Kilimann, MD }\end{array}$ & DZNE, Rostock, Germany & $\begin{array}{l}\text { Drafting and/or revision of } \\
\text { manuscript for important } \\
\text { intellectual content }\end{array}$ \\
\hline $\begin{array}{l}\text { Christoph } \\
\text { Laske, MD }\end{array}$ & DZNE, Tübingen, Germany & $\begin{array}{l}\text { Drafting and/or revision of } \\
\text { manuscript for important } \\
\text { intellectual content }\end{array}$ \\
\hline $\begin{array}{l}\text { Franziska } \\
\text { Maier, MD }\end{array}$ & $\begin{array}{l}\text { University of Cologne, } \\
\text { Germany }\end{array}$ & $\begin{array}{l}\text { Drafting and/or revision of } \\
\text { manuscript for important } \\
\text { intellectual content }\end{array}$ \\
\hline $\begin{array}{l}\text { Coraline } \\
\text { Danielle } \\
\text { Metzger, MD }\end{array}$ & $\begin{array}{l}\text { DZNE, Magdeburg, } \\
\text { Germany }\end{array}$ & $\begin{array}{l}\text { Drafting and/or revision of } \\
\text { manuscript for important } \\
\text { intellectual content }\end{array}$ \\
\hline $\begin{array}{l}\text { Matthias H. } \\
\text { Munk, MD }\end{array}$ & DZNE, Tübingen, Germany & $\begin{array}{l}\text { Drafting and/or revision of } \\
\text { manuscript for important } \\
\text { intellectual content }\end{array}$ \\
\hline $\begin{array}{l}\text { Robert } \\
\text { Perneczky, } \\
\text { MD }\end{array}$ & DZNE, Munich, Germany & $\begin{array}{l}\text { Drafting and/or revision of } \\
\text { manuscript for important } \\
\text { intellectual content }\end{array}$ \\
\hline $\begin{array}{l}\text { Oliver Peters, } \\
\text { MD }\end{array}$ & DZNE, Berlin, Germany & $\begin{array}{l}\text { Drafting and/or revision of } \\
\text { manuscript for important } \\
\text { intellectual content }\end{array}$ \\
\hline $\begin{array}{l}\text { Josef Priller, } \\
\text { MD }\end{array}$ & DZNE, Berlin, Germany & $\begin{array}{l}\text { Drafting and/or revision of } \\
\text { manuscript for important } \\
\text { intellectual content }\end{array}$ \\
\hline $\begin{array}{l}\text { Alfredo } \\
\text { Ramirez, MD }\end{array}$ & $\begin{array}{l}\text { University of Cologne, } \\
\text { Germany }\end{array}$ & $\begin{array}{l}\text { Drafting and/or revision of } \\
\text { manuscript for important } \\
\text { intellectual content }\end{array}$ \\
\hline $\begin{array}{l}\text { Boris-Stephan } \\
\text { Rauchmann, } \\
\text { MD }\end{array}$ & $\begin{array}{l}\text { Ludwig-Maximilians- } \\
\text { University, Munich, } \\
\text { Germany }\end{array}$ & $\begin{array}{l}\text { Drafting and/or revision of } \\
\text { manuscript for important } \\
\text { intellectual content }\end{array}$ \\
\hline
\end{tabular}


Appendix (continued)

\begin{tabular}{|c|c|c|}
\hline Name & Location & Contribution \\
\hline $\begin{array}{l}\text { Nina Roy, } \\
\text { PhD }\end{array}$ & DZNE, Bonn, Germany & $\begin{array}{l}\text { Drafting and/or revision of } \\
\text { manuscript for important } \\
\text { intellectual content }\end{array}$ \\
\hline $\begin{array}{l}\text { Klaus } \\
\text { Scheffler, } \\
\text { PhD }\end{array}$ & $\begin{array}{l}\text { University of Tübingen, } \\
\text { Germany }\end{array}$ & $\begin{array}{l}\text { Drafting and/or revision of } \\
\text { manuscript for important } \\
\text { intellectual content }\end{array}$ \\
\hline $\begin{array}{l}\text { Anja } \\
\text { Schneider, } \\
\text { MD }\end{array}$ & DZNE, Bonn, Germany & $\begin{array}{l}\text { Drafting and/or revision of } \\
\text { manuscript for important } \\
\text { intellectual content }\end{array}$ \\
\hline $\begin{array}{l}\text { Annika } \\
\text { Spottke, MD }\end{array}$ & DZNE, Bonn, Germany & $\begin{array}{l}\text { Drafting and/or revision of } \\
\text { manuscript for important } \\
\text { intellectual content }\end{array}$ \\
\hline $\begin{array}{l}\text { Eike Jakob } \\
\text { Spruth, MD }\end{array}$ & DZNE, Berlin, Germany & $\begin{array}{l}\text { Drafting and/or revision of } \\
\text { manuscript for important } \\
\text { intellectual content }\end{array}$ \\
\hline $\begin{array}{l}\text { Stefan Teipel, } \\
\text { MD }\end{array}$ & DZNE, Rostock, Germany & $\begin{array}{l}\text { Drafting and/or revision of } \\
\text { manuscript for important } \\
\text { intellectual content }\end{array}$ \\
\hline $\begin{array}{l}\text { Ruth } \\
\text { Vukovich, } \\
\text { MD }\end{array}$ & $\begin{array}{l}\text { University of Goettingen, } \\
\text { Germany }\end{array}$ & $\begin{array}{l}\text { Drafting and/or revision of } \\
\text { manuscript for important } \\
\text { intellectual content }\end{array}$ \\
\hline $\begin{array}{l}\text { Jens } \\
\text { Wiltfang, MD }\end{array}$ & DZNE, Goettingen, Germany & $\begin{array}{l}\text { Drafting and/or revision of } \\
\text { manuscript for important } \\
\text { intellectual content }\end{array}$ \\
\hline $\begin{array}{l}\text { Frank Jessen, } \\
\text { MD }\end{array}$ & DZNE, Bonn, Germany & $\begin{array}{l}\text { Conceptualization and } \\
\text { design of the study; Drafting } \\
\text { and/or revision of } \\
\text { manuscript for important } \\
\text { intellectual content }\end{array}$ \\
\hline $\begin{array}{l}\text { Michael } \\
\text { Wagner, PhD }\end{array}$ & DZNE, Bonn, Germany & $\begin{array}{l}\text { Conceptualization and } \\
\text { design of the study; } \\
\text { Interpretation of data; } \\
\text { Drafting and/or revision of } \\
\text { manuscript for important } \\
\text { intellectual content }\end{array}$ \\
\hline
\end{tabular}

\section{Appendix 2 Coinvestigators}

Coinvestigators are listed at links.Iww.com/WNL/B405

\section{References}

1. Scarmeas N, Stern Y, Tang MX, Mayeux R, Luchsinger JA. Mediterranean diet and risk for Alzheimer's disease. Ann Neurol. 2006;59(6):912-921.

2. Lourida I, Soni M, Thompson-Coon J, et al. Mediterranean diet, cognitive function, and dementia: a systematic review. Epidemiology. 2013;24(4):479-489.

3. Petersson SD, Philippou E. Mediterranean diet, cognitive function, and dementia: a systematic review of the evidence. Adv Nutr. 2016;7(5):889-904.

4. Sofi F, Cesari F, Abbate R, Franco Gensini G, Casini A. Adherence to Mediterranean diet and health status: meta-analysis. BMJ. 2008;337:a1344.

5. Akbaraly T, Sexton C, Zsoldos E, et al. Association of long-term diet quality with hippocampal volume: longitudinal cohort study. Am J Med. 2018;131(11): 1372-1381.e4.

6. Psaltopoulou T, Kyrozis A, Stathopoulos P, Trichopoulos D, Vassilopoulos D, Trichopoulou A. Diet, physical activity and cognitive impairment among elders: the EPIC-Greece cohort (European Prospective Investigation Into Cancer and Nutrition). Public Health Nutr. 2008;11(10):1054-1062.

7. Valls-Pedret C, Sala-Vila A, Serra-Mir M, et al. Mediterranean diet and age-related cognitive decline: a randomized clinical trial. JAMA Intern Med. 2015;175(7): 1094-1103.

8. Martínez-Lapiscina EH, Clavero P, Toledo E, et al. Virgin olive oil supplementation and long-term cognition: the PREDIMED-NAVARRA randomized, trial. $J$ Nutr Health Aging. 2013;17(6):544-552.
9. Singh B, Parsaik AK, Mielke MM, et al. Association of Mediterranean diet with mild cognitive impairment and Alzheimer's disease: a systematic review and meta-analysis. J Alzheimers Dis. 2014;39(2):271-282.

10. Scarmeas N, Stern Y, Mayeux R, Manly JJ, Schupf N, Luchsinger JA. Mediterranean diet and mild cognitive impairment. Arch Neurol. 2009;66(2):216-225.

11. Matthews DC, Davies M, Murray J, et al. Physical activity, Mediterranean diet and biomarkers-assessed risk of Alzheimer's: a multi-modality brain imaging study. Adv J Mol Imaging. 2014;4(4):43-57.

12. Mosconi L, Murray J, Tsui WH, et al. Mediterranean diet and magnetic resonance imaging-assessed brain atrophy in cognitively normal individuals at risk for Alzheimer's disease. J Prev Alzheimers Dis. 2014;1(1):23-32.

13. Staubo SC, Aakre JA, Vemuri P, et al. Mediterranean diet, micronutrients and macronutrients, and MRI measures of cortical thickness. Alzheimers Dement. 2017;13(2) 168-177.

14. Gu Y, Brickman AM, Stern Y, et al. Mediterranean diet and brain structure in a multiethnic elderly cohort. Neurology. 2015;85(20):1744-1751.

15. Karstens AJ, Tussing-Humphreys L, Zhan L, et al. Associations of the Mediterranean diet with cognitive and neuroimaging phenotypes of dementia in healthy older adults. Am J Clin Nutr. 2019;109(2):361-368.

16. Vassilaki M, Aakre JA, Syrjanen JA, et al. Mediterranean diet, its components, and amyloid imaging biomarkers. J Alzheimers Dis. 2018;64(1):281-290.

17. Berti V, Walters M, Sterling J, et al. Mediterranean diet and 3-year Alzheimer brain biomarker changes in middle-aged adults. Neurology. 2018;90(20):e1789-e1798.

18. Hill E, Szoeke C, Dennerstein L, Campbell S, Clifton P. Adherence to the Mediterranean diet is not related to beta-amyloid deposition: data from the Women's Healthy Ageing Project. J Prev Alzheimers Dis. 2018;5(4):137-141.

19. Merrill DA, Siddarth P, Raji CA, et al. Modifiable risk factors and brain positron emission tomography measures of amyloid and tau in nondemented adults with memory complaints. Am J Geriatr Psychiatry. 2016;24(9):729-737.

20. Rainey-Smith SR, Gu Y, Gardener SL, et al. Mediterranean diet adherence and rate of cerebral a $\beta$-amyloid accumulation: data from the Australian Imaging, Biomarkers and Lifestyle Study of Ageing. Transl Psychiatry. 2018;8(1):238.

21. Jessen F, Spottke A, Boecker H, et al. Design and first baseline data of the DZNE multicenter observational study on predementia Alzheimer's disease (DELCODE). Alzheimers Res Ther. 2018;10(1):15.

22. Jessen F, Amariglio RE, van Boxtel M, et al. A conceptual framework for research on subjective cognitive decline in preclinical Alzheimer's disease. Alzheimers Dement. 2014;10(6):844-852.

23. Molinuevo JL, Rabin LA, Amariglio R, et al. Implementation of subjective cognitive decline criteria in research studies. Alzheimers Dement. 2017;13(3):296-311.

24. Albert MS, DeKosky ST, Dickson D, et al. The diagnosis of mild cognitive impairment due to Alzheimer's disease: recommendations from the National Institute on AgingAlzheimer's Association workgroups on diagnostic guidelines for Alzheimer's disease. Alzheimers Dement. 2011;7(3):270-279.

25. Washburn RA, Smith KW, Jette AM, Janney CA. The Physical Activity Scale for the Elderly (PASE): development and evaluation. J Clin Epidemiol. 1993;46(2): 153-162.

26. Wolfsgruber S, Kleineidam L, Guski J, et al. Minor neuropsychological deficits in patients with subjective cognitive decline. Neurology. 2020;95(9):e1134-e1143.

27. Noethlings U, Hoffmann K, Bergmann MM, Boeing H. Portion size adds limited information on variance in food intake of participants in the EPIC-Potsdam study. J Nutr. 2003;133(2):510-515

28. Trichopoulou A, Costacou T, Bamia C, Trichopoulos D. Adherence to a Mediterranean diet and survival in a Greek population. N Engl J Med. 2003;348(26) 2599-2608.

29. Wiltfang J, Esselmann H, Bibl M, et al. Amyloid beta peptide ratio $42 / 40$ but not A beta 42 correlates with phospho-tau in patients with low- and high-CSF A beta 40 load. J Neurochem. 2007;101(4):1053-1059.

30. Ashburner J, Friston KJ. Voxel-based morphometry: the methods. Neuroimage. 2000; 11(6):805-821.

31. Braak H, Braak E. Staging of Alzheimer's disease-related neurofibrillary changes. Neurobiol Aging. 1995;16(3):271-278.

32. Selkoe DJ, Hardy J. The amyloid hypothesis of Alzheimer's disease at 25 years. EMBO Mol Med. 2016;8(6):595-608.

33. Stern Y, Arenaza-Urquijo EM, Bartrés-Faz D, et al. Whitepaper: defining and investigating cognitive reserve, brain reserve, and brain maintenance. Alzheimers Dement. 2020;16(9):1305-1311.

34. Pelletier A, Barul C, Féart C, et al. Mediterranean diet and preserved brain structural connectivity in older subjects. Alzheimers Dement. 2015;11(9):1023-1031.

35. Titova OE, Ax E, Brooks SJ, et al. Mediterranean diet habits in older individuals: associations with cognitive functioning and brain volumes. Exp Gerontol. 2013; 48(12):1443-1448

36. Wesselman LMP, Melo van Lent D, Schröder A, et al. Dietary patterns are related to cognitive functioning in elderly enriched with individuals at increased risk for $\mathrm{Alz}$ heimer's disease. Eur J Nutr. 2021;60(2):849-860.

37. Anastasiou CA, Yannakoulia M, Kosmidis MH, et al. Mediterranean diet and cognitive health: initial results from the Hellenic Longitudinal Investigation of Ageing and Diet. PLoS One. 2017;12(8):e0182048.

38. Loughrey DG, Lavecchia S, Brennan S, Lawlor BA, Kelly ME. The impact of the Mediterranean diet on the cognitive functioning of healthy older adults: a systematic review and meta-analysis. Adv Nutr. 2017;8(4):571-586.

39. Samieri C, Grodstein F, Rosner BA, et al. Mediterranean diet and cognitive function in older age. Epidemiology. 2013;24(4):490-499. 
40. Su Kwak S, Washicosky KJ, Brand E, et al. Amyloid- $\beta 42 / 40$ ratio drives tau pathology in 3D human neural cell culture models of Alzheimer's disease. Nat Commun. 2020; 11(1):1-14.

41. Kinney JW, Bemiller SM, Murtishaw AS, Leisgang AM, Salazar AM, Lamb BT. Inflammation as a central mechanism in Alzheimer's disease. Alzheimers Dement. 2018;4: 575-590.

42. Tosti V, Bertozzi B, Fontana L. Health benefits of the Mediterranean diet: metabolic and molecular mechanisms. J Gerontol A Biol Sci Med Sci. 2018;73(3):318-326.

43. Tönnies E, Trushina E. Oxidative stress, synaptic dysfunction, and Alzheimer's disease. J Alzheimers Dis. 2017;57(4):1105-1121.

44. Qosa H, Mohamed LA, Batarseh YS, et al. Extra-virgin olive oil attenuates amyloid- $\beta$ and tau pathologies in the brains of TgSwDI mice. J Nutr Biochem. 2015;26(12):1479-1490.

45. Scarmeas N, Luchsinger JA, Schupf N, et al. Physical activity, diet, and risk of Alzheimer disease. JAMA. 2009;302(6):627-637.
46. Wagner M, Grodstein F, Proust-Lima C, Samieri C. Long-term trajectories of body weight, diet, and physical activity from midlife through late life and subsequent cognitive decline in women. Am J Epidemiol. 2020;189(4):305-313.

47. Jin Q, Black A, Kales SN, Vattem D, Ruiz-Canela M, Sotos-Prieto M. Metabolomics and microbiomes as potential tools to evaluate the effects of the Mediterranean diet. Nutrients. 2019;11(1):207.

48. Barabási AL, Menichetti G, Joseph L. The unmapped chemical complexity of our diet. Nat Food. 2020;1:33-37.

49. van de Rest O, Am Berendsen A, Haveman-Nies A, de Groot LC. Dietary patterns, cognitive decline, and dementia: a systematic review. Adv Nutr. 2015;6(2):154-168. 50. Dinu M, Pagliai G, Casini A, Sofi F. Mediterranean diet and multiple health outcomes: an umbrella review of meta-analyses of observational studies and randomised trials. Eur J Clin Nutr. 2018;72(1):30-43. 


\section{Neurology}

\section{Mediterranean Diet, Alzheimer Disease Biomarkers, and Brain Atrophy in Old Age}

Tommaso Ballarini, Debora Melo van Lent, Julia Brunner, et al.

Neurology 2021;96;e2920-e2932 Published Online before print May 5, 2021

DOI 10.1212/WNL.0000000000012067

This information is current as of May 5, 2021

\section{Updated Information \& Services}

References

Citations

Subspecialty Collections

Permissions \& Licensing

Reprints including high resolution figures, can be found at: http://n.neurology.org/content/96/24/e2920.full

This article cites 50 articles, 9 of which you can access for free at: http://n.neurology.org/content/96/24/e2920.full\#ref-list-1

This article has been cited by 2 HighWire-hosted articles: http://n.neurology.org/content/96/24/e2920.full\#\#otherarticles

This article, along with others on similar topics, appears in the following collection(s):

\section{Alzheimer's disease}

http://n.neurology.org/cgi/collection/alzheimers_disease

\section{Memory}

http://n.neurology.org/cgi/collection/memory

MRI

http://n.neurology.org/cgi/collection/mri

Information about reproducing this article in parts (figures,tables) or in its entirety can be found online at:

http://www.neurology.org/about/about_the_journal\#permissions

Information about ordering reprints can be found online:

http://n.neurology.org/subscribers/advertise

Neurology ${ }^{\circledR}$ is the official journal of the American Academy of Neurology. Published continuously since 1951, it is now a weekly with 48 issues per year. Copyright @ 2021 American Academy of Neurology. All rights reserved. Print ISSN: 0028-3878. Online ISSN: 1526-632X.

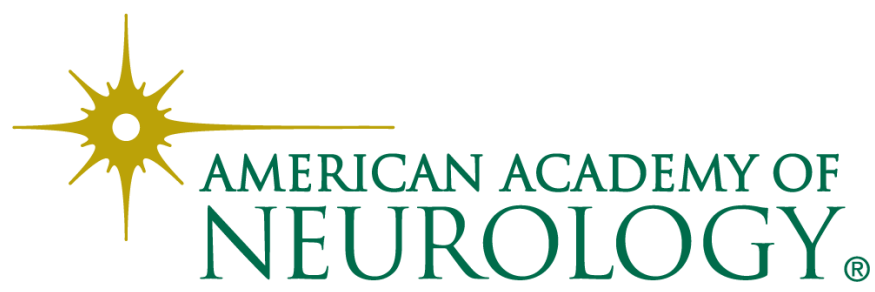

